\title{
7. HYDROGRAPHY OF THE SULU SEA ${ }^{1}$
}

\author{
Andrea Frische ${ }^{2}$ and Detlef Quadfasel ${ }^{2}$
}

\section{INTRODUCTION}

Like most other deep basins in the eastern Indonesian archipelago, the deep Sulu Basin is isolated from the neighboring basins by surrounding shallower topography. Therefore, its hydrographic and dynamic characteristics are representative for the deep basins of the archipelago. While the near-surface circulation is mainly governed by the seasonally reversing monsoon winds, the deep circulation is forced by an inflow of intermediate water from the South China Sea through the Mindoro Strait (sill depth $420 \mathrm{~m}$ ), which supplies the intermediate and bottom waters of the Sulu Sea (Wyrtki, 1961). Below $1000 \mathrm{~m}$ temperatures and salinities in the Sulu Sea are remarkably homogeneous $\left(\theta=9.8^{\circ}-10.0^{\circ} \mathrm{C}, \mathrm{S}=34.48\right)$. Tracer data (Broecker et al., 1986 ) suggest renewal times of $50-100 \mathrm{yr}$.

In the past only few hydrographic data were collected in the Sulu Sea. This sparse data set did not allow the delineation of a detailed pattern of deep circulation and water mass renewal. For this reason a closely spaced hydrographic section from the South China Sea to the central Sulu Sea was occupied during cruise SO 58 (Fig. 1, Table 1). The main objectives of this program were:

1. to map the structure and depth of the core of the inflowing intermediate water from the South China Sea in detail;

2 . to estimate the mixing of this water with the ambient waters in the Mindoro Strait and the slope region in the northern Sulu Basin; and

3. to investigate the influence of geothermal heating on the deep waters and the vertical circulation of the Sulu Sea.

Apart from conductivity, temperature, and pressure (CTD) casts, water samples were taken at up to 12 depth levels and analyzed for salinity, dissolved oxygen, and nutrient contents.

Here we present preliminary results from this investigation, based upon the hydrographic bottle data and the CTD temperatures.

\section{DATA COLLECTION}

Temperature and salinity profiles were obtained with two ME-Multisonde CTDs providing data with a resolution of 0.2 dbar for pressure, $0.0015^{\circ} \mathrm{C}$ for temperature, and $0.002 \mathrm{mS} / \mathrm{cm}$ for conductivity. The CTDs were supplemented by a Hydrobios rosette sampler equipped with twelve 5-L bottles. Two bottles carried protected and unprotected reversing thermometers. The raw data from the CTD were stored directly on digital magnetic tape at a rate of 8 cycles per second. In addition, every eighth cycle was logged onto a personal computer to serve as a basis for quick-look plots and printouts. After the failure of the first

\footnotetext{
${ }^{1}$ Rangin, C., Silver, E., von Breymann, M. T., et al., 1990. Proc. ODP, Init. Repts., 124: College Station, TX (Ocean Drilling Program).

2 Institut für Meereskunde, der Universität Hamburg, Troplowitzstrasse 7, 2000 Hamburg 54, Federal Republic of Germany.
}

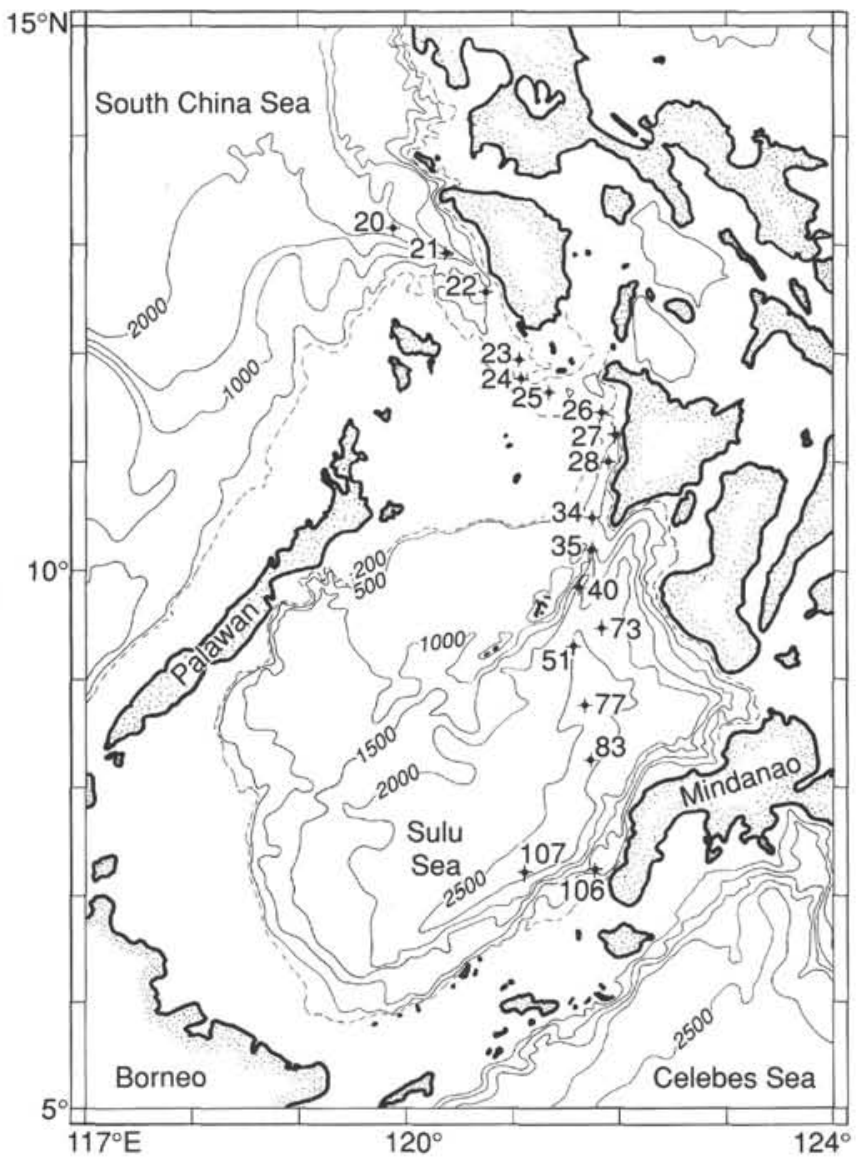

Figure 1. Location of hydrographic stations in the South China Sea and Sulu Sea during cruise SO 58, 28 August to 17 September, 1988. Depth contours are in fathoms.

CTD, the remaining two casts were recorded on the VAX computer of the Sonne.

The oxygen samples were analyzed on board with a Hydrobios tritration stand using the Winkler method. Reproducibility on duplicate samples was better than $0.07 \mathrm{mg} / \mathrm{L}$. The salinity samples were analyzed after the cruise, at the Institut für Meereskunde in Hamburg using a Guildine Autosal Salinometer. Even with a storage time of 3 months, accuracy was better than $\pm 0.003 \%$. The nutrient samples were fixed with mercuric chloride $\left(\mathrm{HgCl}_{2}\right)$ and analyzed in Hamburg at the Institut für Biochemie und Lebensmittelchemie (U. Brockmann). Nominal accuracies are $0.7 \%$ for nitrate, $3 \%$ for phosphate, and $0.5 \%$ for dissolved silica. However, as the nutrient samples had not been filtered, there may be a systematic error due to absorption that results in a linear reduction of the phosphate and dissolved silica values. Although a direct comparison with earlier data is therefore impossible, the relative structure of the profiles in the Sonne data set is correct. 
A. FRISCHE, D. QUADFASEL

Table 1. List of hydrographic stations occupied during SO 58.

\begin{tabular}{|c|c|c|c|c|c|}
\hline Station & $\begin{array}{l}\text { Date } \\
\text { (1988) }\end{array}$ & $\begin{array}{l}\text { Time } \\
\text { (local) }\end{array}$ & Latitude & Longitude & $\begin{array}{l}\text { Depth } \\
\text { [dbar] }\end{array}$ \\
\hline 19 & 28.8 & $7.30-7.58$ & $13^{\circ} 55.18^{\circ} \mathrm{N}$ & $119^{\circ} 53.51^{\prime} \mathrm{E}$ & 1207 \\
\hline 20 & 28.8 & $13.00-16.15$ & $13^{\circ} 08.81^{\circ} \mathrm{N}$ & $119^{\circ} 53.62^{\circ} \mathrm{E}$ & 4656 \\
\hline 21 & 28.8 & $19.10-21.20$ & $12^{\circ} 55.85^{\circ} \mathrm{N}$ & $120^{\circ} 22.67^{\circ} \mathrm{E}$ & 2328 \\
\hline 22 & 29.8 & $00.10-01.05$ & $12^{\circ} 33.98^{\circ} \mathrm{N}$ & $120^{\circ} 45.79^{\prime} \mathrm{E}$ & 840 \\
\hline 23 & 29.8 & $04.50-05.25$ & $11^{\circ} 56.52^{\prime} \mathrm{N}$ & $121^{\circ} \mathrm{O} 4.20^{\circ} \mathrm{E}$ & 433 \\
\hline 24 & 29.8 & $06.50-08.00$ & $11^{\circ} 46.14^{\circ} \mathrm{N}$ & $121^{\circ} 05.18^{\prime} \mathrm{E}$ & 619 \\
\hline 25 & 29.8 & $11.20-12.20$ & $11^{\circ} 38.48^{\circ} \mathrm{N}$ & $121^{\circ} 20.70^{\circ} \mathrm{E}$ & 758 \\
\hline 26 & 29.8 & $15.35-17.05$ & $11^{\circ} 27.56^{\circ} \mathrm{N}$ & $121^{\circ} 49.66^{\circ} \mathrm{E}$ & 1077 \\
\hline 27 & 29.8 & $19.10-20.15$ & $11^{\circ} 14.76^{\circ} \mathrm{N}$ & $121^{\circ} 57.85^{\circ} \mathrm{E}$ & 838 \\
\hline 28 & 29.8 & $21.50-23.05$ & $11^{\circ} 00.66^{\prime} \mathrm{N}$ & $121^{\circ} 54.82^{\circ} \mathrm{E}$ & 1215 \\
\hline 34 & 31.8 & $00.15-01.40$ & $10^{\circ} 29.90^{\circ} \mathrm{N}$ & $121^{\circ} 45.10^{\circ} \mathrm{E}$ & 1397 \\
\hline 35 & 31.8 & $03.55-06.30$ & $10^{\circ} 10.33^{\circ} \mathrm{N}$ & $121^{\circ} 42.46^{\circ} \mathrm{E}$ & 2912 \\
\hline 40 & 1.9 & $03.10-06.00$ & $9^{\circ} 50.75^{\circ} \mathrm{N}$ & $121^{\circ} 37.17^{\circ} \mathrm{E}$ & 3949 \\
\hline 51 & 3.9 & $09.05-12.45$ & $9^{\circ} 18.677^{\prime} \mathrm{N}$ & $121^{\circ} 34.27^{\circ} \mathrm{E}$ & 4834 \\
\hline 73 & 9.9 & $01.05-04.10$ & $9^{\circ} 28.00^{\prime} \mathrm{N}$ & $121^{\circ} 51.08^{\circ} \mathrm{E}$ & 4143 \\
\hline 77 & 10.9 & $02.33-05.55$ & $8^{\circ} 45.60^{\circ} \mathrm{N}$ & $121^{\circ} 41.00^{\prime} \mathrm{E}$ & 4873 \\
\hline 83 & 12.9 & $00.05-03.19$ & $\mathrm{~B}^{\circ} 14.94^{\circ} \mathrm{N}$ & $121^{\circ} 43.98^{\circ} \mathrm{E}$ & 5064 \\
\hline 106 & 17.9 & $11.15-11.59$ & $7^{\circ} 12.21^{\circ} \mathrm{N}$ & $121^{\circ} 46.41^{\circ} \mathrm{E}$ & 454 \\
\hline 107 & 17.9 & $21.12-00.51$ & $7^{\circ} 12.08^{\circ} \mathrm{N}$ & $121^{\circ} \mathrm{O} .14^{\circ} \mathrm{E}$ & 4725 \\
\hline
\end{tabular}

Altogether, 18 hydrographic profiles were obtained with a total of 198 water samples.

\section{DISCUSSION}

The vertical distribution of potential temperature, salinity, dissolved oxygen, and silicate content is shown in Figure 2.

Below the warm and fresh surface layer, the core of the Subtropical Lower Water from the Pacific Ocean can be seen around $200 \mathrm{~m}$ depth as a very distinct salinity maximum. It lies well above the sill depth in the Mindoro Strait and its spreading is thus not hampered by topography.

North Pacific Intermediate Water, characterized by a salinity and oxygen minimum at temperatures between $7.5^{\circ}$ and $9.5^{\circ} \mathrm{C}$, is clearly visible in the South China Sea at depths between 400 and $800 \mathrm{~m}$. This water is the primary source for the intermediate and deep waters of the Sulu Sea. A low-salinity core originating from this minimum can be traced across the Sulu Sea in the 600 - to $1400-\mathrm{m}$ depth layer. Is is associated with a relative maximum in oxygen content and a vertically homogeneous silicate concentration. Temperatures here are higher than in the corresponding layer in the South China Sea, presumably due to tidally induced vertical mixing in the Mindoro Strait. The high oxygen concentrations (high compared with earlier data; Wyrtki, 1961; Broecker, et al., 1986) suggest that this intrusion of intermediate water occurred relatively recently.

The buildup of this intermediate layer and the effects of the sills in the Mindoro Strait in cutting off the lower portion of the Pacific Intermediate Water is illustrated in Figure 3. Here vertical profiles of silicate content from the South China Sea, the Mindoro Strait, and the Sulu Sea are shown. The first sill off Mindoro between stations 22 and $23(470 \mathrm{~m})$ limits the inflow to water with silicate values $<58 \mu \mathrm{M}$, and the southern sill west of Panay $(420 \mathrm{~m}$, between stations 26 and 27$)$ gives a cut-off at 50 $\mu \mathrm{M}$. This overflow water plunges down the slope into the Sulu Sea, forming a quasi-homogeneous layer of $1000 \mathrm{~m}$ thickness.
In the deep-water regime below about $2500 \mathrm{~m}$ depth, the vertical and horizontal gradients of the hydrographic properties are small. There is a tendency for the deep water in the northern Sulu Sea to be slightly fresher and warmer and to have higher oxygen content compared to the deep water in the south (Fig. 2). The high temperature, low salinity, and high oxygen content are indicative of an intrusion of northern Pacific Intermediate Water in the deep northern Sulu Sea. Deep plume convection down the continental slope is a likely generation mechanism. However, due to its high temperature and low salinity, this plume water is less dense than the deep water in the central basin and therefore convection should not have occurred.

So far this apparent contradiction remains a puzzle. A possible explanation is that the deep convection occurs in the form of turbidity currents, where the sediment load increases the density of the sinking plume. However, this interpretation is very speculative at this time and requires further investigation.

The maximum depth of the renewal depends strongly on the density of the water inflowing through the Mindoro Strait (Fig. 4). The shallower the thermocline in the South China Sea, the denser the overflow water and the deeper the convection in the Sulu Sea. A possible mechanism for thermocline uplifting is the passage of tropical cyclones. Two major storms passed the area during August 1987, causing catastrophic flooding in the Philippines. This event may have been responsible for the intermediate depth intrusion in the Sulu Sea, as observed in August 1988.

\section{REFERENCES}

Broecker, W. S., Patzert, W. C., Toggweiler, J. R., and Stuivr, M., 1986. Hydrography, chemistry and radioisotopes in the southeast Asian Waters. J. Geophys. Res., 91:14,345-14,354.

Wyrtki, K., 1961. Scientific results of marine investigations of the South China Sea and the Gulf of Thailand, 1959-1961. NAGA Rep. 2: LaJolla, CA (Scripps Institution of Oceanography).

Ms 124A-107 

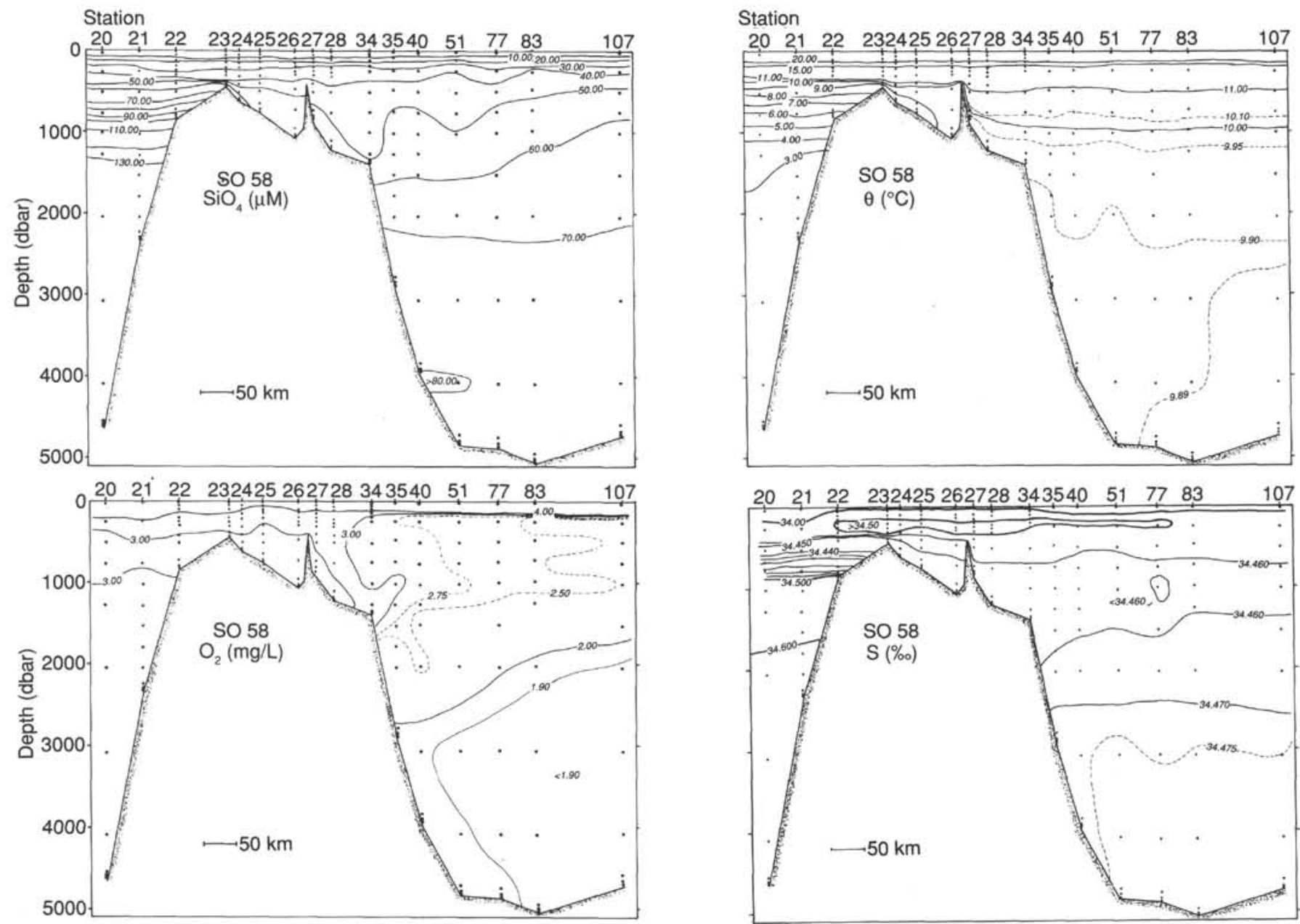

Figure 2. Vertical distributions of dissolved silica $(\mu \mathrm{M})$, potential temperature $\left({ }^{\circ} \mathrm{C}\right)$, dissolved oxygen $(\mathrm{mg} / \mathrm{L})$, and salinity $(\% \circ)$ along the hydrographic section.

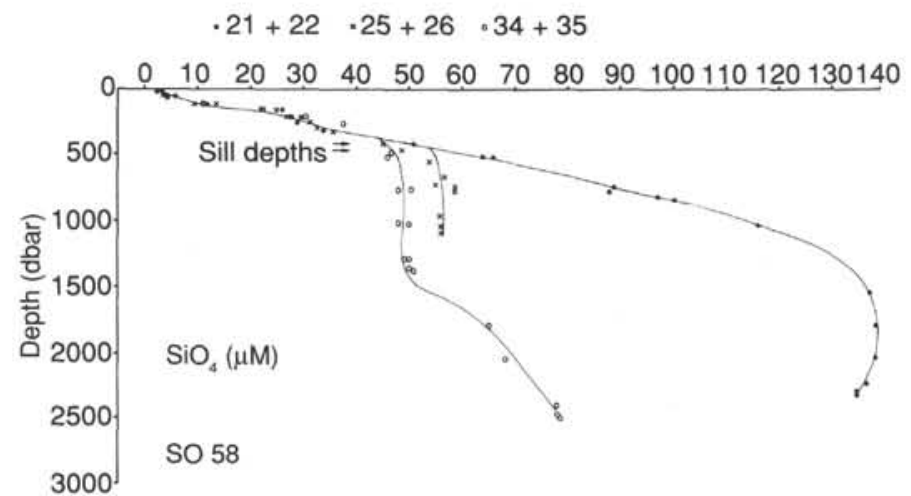

Figure 3. Profiles of dissolved silicate content $(\mu \mathrm{M})$ in the South China Sea (Stations 21 and 22), between the sills in the Mindoro Strait ( 25 and 26), and in the northern Sulu Sea (34 and 35). For explanation see text. 
A. FRISCHE, D. QUADFASEL

South China Sea

Sulu Sea

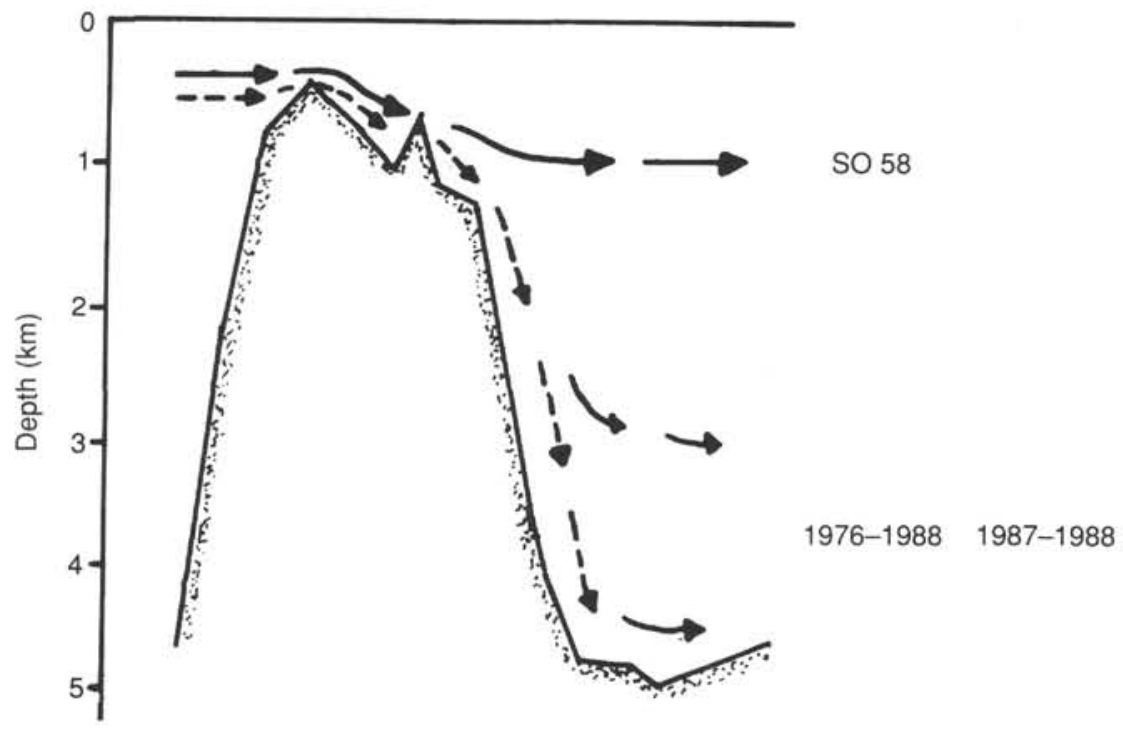

Figure 4. Scheme of the deep- and intermediate-water renewal in the Sulu Sea. The mode of water renewal in the Sulu Sea depends strongly on the thermocline depth in the southern South China Sea. 